\title{
PAAUGLIŲ SOCIALINIO NERIMO SĄSAJOS SU MENTALIZACIJA IR TRAUMINE PATIRTIMI
}

\author{
Gabrielė Skabeikytė, Rasa Barkauskienė, Lina Gervinskaitė-Paulaitienė \\ Vilniaus universiteto Filosofijos fakulteto Psichologijos institutas
}

Raktažodžiai: socialinis nerimas, reflektyvioji funkcija, trauminé patirtis, paauglystè.

\begin{abstract}
Santrauka
Tyrimo tikslas buvo ịvertinti paauglių socialinio nerimo, mentalizacijos ir trauminès patirties sąsajas. Socialinis nerimas - aktuali problema, paprastai prasidedanti jau ankstyvoje paauglystëje ir įvairiapusiškai trikdanti asmens funkcionavimą. Analizuojant nerimo raidai svarbius veiksnius, tyrimai atskleidžia ryšị tarp vaikystès trauminių patirčių bei socialinio nerimo vèlesniame amžiuje. Socialiniam nerimui būdingos klaidingos kitų asmenų elgesio interpretacijos, tad tai gali būti susiję su paauglio gebejjimu interpretuoti savo ir kitų poelgius. Visgi atlikti tyrimai paliečia bendrą socialinio nerimo patyrimą arba atskirus mentalizacijos aspektus, nejungiant jų ị visumą, o trauminès patirties vaidmuo šioje sąveikoje neaiški. Lietuvoje tokie tyrimai tik įsibègejja, trūksta metodų įvertinti paaugliu patiriamam socialiniam nerimui. Tyrimo dalyviai buvo $68011-14 \mathrm{~m}$. paaugliai (331 vaikinas ir 349 merginos) iš skirtingu Lietuvos mokyklu bei globos namų. Instrumentai. Liebowitz socialinio nerimo skalè vaikams ir paaugliams (LSAS-CA), Reflektyviosios funkcijos klausimynas (RFQY) bei Vaikystės patirčių klausimynas (VPK). Rezultatai. Traumine patirtis yra susijusi su prastesne mentalizacija, vertinta kaip reflektyvioji funkcija, bei aukštesniais socialinio nerimo įverčiais. Aukštesni socialinio nerimo įverčiai yra susiję su prastesne reflektyviaja funkcija. Nustatyta, jog trauminès patirties ir socialinio nerimo sąsaja kinta esant skirtingam paauglio mentalizacijos lygiui: kuo geresnè mentalizacija, tuo silpnesnis ryšys tarp smurto patyrimo ir socialinio nerimo paauglysteje. Tai reiškia, kad aukšta mentalizacija atlieka apsauginio veiksnio funkciją.
\end{abstract}

\section{Ivadas}

Nerimo sutrikimai yra vieni dažniausių paauglystejje [1].
Paauglyste laikoma itin jautriu laikotarpiu, kuomet vyksta daugybe fiziologinių ir psichologinių pokyčių, sparčiai tobulëja kognityviniai gebëjimai, keičiasi tarpasmeninių santykių supratimas, juose smalsumą pakeičia didėjanti emocijų supratimo ir empatijos svarba [2]. Nepaprastai svarbi tampa ir bendraamžių bei autoritetų nuomonè, didèja tarpasmeniniu santykiu poveikis, tad paauglys tampa labai jautrus aplinkos įtakai, o santykiai - vienu iš nerimo šaltinių. Tiesiogiai su socialiniais santykiais susijęs sutrikimas yra socialinio nerimo sutrikimas, kurio formavimosi pradžia siejama su ankstyvaja paauglyste [3]. Paauglių raidos ypatumai ir sutrikimo aktualumas būtent šiuo laikotarpiu skatina daugiau domètis paauglių socialinio nerimo patyrimu.

Socialinis nerimas apibrěžiamas kaip nerimas, kylantis socialinèse situacijose, kuriose asmuo gali būti tiesiogiai vertinamas kitų žmonių. Dẻl numanomo neigiamo ịvertinimo asmuo siekia tokių situacijų išvengti [3]. Socialinio nerimo patyrimas gali ženkliai trikdyti paauglio funkcionavimą: socialini nerimą patiriantis paauglys gali vengti valgyti viešose vietose, naudotis viešuoju tualetu, kalbèti su nepažįstamaisiais, dirbti bendraamžiu grupelèse, kalbèti prieš klasę ir panašiai [1]. Nerimastingi paaugliai pasižymi žemesne asmenine gerove, prastu akademiniu funkcionavimu, apribojamos laisvalaikio veiklos vengiant tų, kurios kelia nerimą [4]. Taip pat yra duomenų apie komorbidiškumą su kitais sutrikimais: besitęsiantis sutrikimas didina depresijos, kitu nerimo sutrikimų, savižudybès, piknaudžiavimo alkoholiu riziką suaugusiojo amžiuje [5,6]. Taigi, socialinio nerimo patyrimas trukdo užmegzti tenkinančius tarpasmeninius santykius ir taip menkina asmens gerovę skirtingose srityse bei yra susijęs su kitų sutrikimų rizika. Socialinio nerimo patyrimas gali paliesti skirtingas asmens funkcionavimo sritis, tad problema tampa ir visuomenès sveikatos problemų dalimi.

Socialinis nerimas kyla iš klaidingų kitų žmonių elgesio interpretacijų [7] ir teoriškai tai turètų būti glaudžiai susiję su gebejjimu mentalizuoti - suprasti savo ir kitų žmonių vidines būsenas bei paaiškinti savo ir kitų elgesi atsižvelgiant i jas. Literatūroje dažnai kaip sinonimas mentalizacijai vartojama reflektyvios funkcijos sąvoka, kuri apima išskirtinai anksty- 
vojo prieraišumo kontekste besiformuojantị gebėjimą reflektuoti save ir kitą $[8,9]$. Autoriai aprašo kelis mentalizacijos aspektus, kurie atskleidžia, jog mentalizacija gali būti tiek sąmoninga, tiek nesąmoninga bei apima ne tik emocijų, bet ir motyvų bei minčių ịsivaizdavimą [9]. Fonagy ir kolegų teigimu, mentalizacija (arba reflektyvioji funkcija) vystosi nuo pat pirmujų gyvenimo metų [9]. Ostler ir kolegų atliktas tyrimas rodo, kad geresnius mentalizacijos ịgūdžius turintys paaugliai turi mažiau psichikos sveikatos problemų, geriau supranta savo jausmus, turi mažiau socialinių ir dèmesio problemų, demonstruoja mažiau agresyvaus elgesio, mažiau depresiškų būsenų, lyginant su prastesnius mentalizacijos igūdžius turinčiais paaugliais [10]. Tuo tarpu mentalizacijos trūkumai susiję su vèliau raidoje patiriamais psichikos sveikatos bei socialiniais sunkumais (nerimo sutrikimai, depresiškumas) [10]. Svarbu tai, kad tyrimai rodo, jog mentalizacijos gebejimas kinta ne tik raidos metu, bet ir kaip gyvenimo ịvykių, su kuriais asmuo susiduria, pasekmé [11]. Tai nurodo, kad mentalizacija yra gyvenimo eigoje kintantis gebejjimas bei turi stiprų teigiamą ir net prevencinị poveiki asmens raidai ir gerovei ir, priešingai, jos deficitai gali pasireikšti kitų funkcionavimo sferų sutrikdymu.

Mentalizacija mažai tyrinèta socialinị nerimą patiriančių asmenų grupėse, tačiau yra duomenų apie prastesnès mentalizacijos ir nerimo sutrikimų ryšį paauglysteje [6,7]. Tai suteikia pagrindą galvoti, kad gebejjimas mentalizuoti yra svarbus ir socialinio nerimo sunkumų turinčiųjų grupèje. Visgi daugelis tyrimų atlikta suaugusiųjų imtyje, tad trūksta duomenų apie ankstyvujų paauglių patyrimą. Tokiu būdu lieka neaišku, kokią funkciją mentalizacija atlieka socialinio nerimo raidoje bei kokios šių veiksnių sąveikos yra būtent ankstyvojoje paauglysteje. Taip pat galbūt mentalizacija šioje amžiaus grupejje galètų atlikti apsauginio veiksnio funkciją, ị kurią tokiu atveju galètų būti kreipiama ankstyvoji intervencija.

Socialinio nerimo patyrimas bei prastesni mentalizacijos gebejjimai gali būti matomi kaip raidos pasekmèje atsirandantys deficitai, tad svarbu būtų svarstyti, kas paskatina šiuos pokyčius. Trauminiai patyrimai ankstyvajame amžiuje gali sutrikdyti tolimesnę vaiko raidą ir tokiu būdu turèti ilgalaikių padarinių [15]. Tyrimai atskleidžia, kad daugiau nei pusė patiriančių socialinį nerimą suaugusiujų vaikystėje patyrè bent vienos rūšies nepriežiūrą [12]. Visgi mažai analizuota, kiek trauma arba nepalankios vaikystès patirtys yra susiję su socialinio nerimo patyrimu būtent ankstyvosios paauglystès laikotarpiu. Tyrimuose taip pat aprašomos sąsajos tarp trauminès patirties ir mentalizacijos, kuriuose nurodoma, kad vaikysteje patirtos traumos, pavyzdžiui, fizinis ar seksualinis smurtas gali lemti, kad vaiko emocijų apdorojimas ir gebėjimas mentalizuoti nebus pakankamai išvystyti. Tai reiškia, kad dèl tokių traumų vystosi menkesni mentalizacijos igūdžiai lyginant su vaikais, kurie tokių patirčių neturèjo $[13,14]$. Galima kelti hipotezę, jog trauminè patirtis yra svarbus kintamasis, kuris gali paskatinti tiek socialinio nerimo raišką, tiek mentalizacijos deficitus.

Taigi, yra žinoma, kad nerimo sutrikimai yra susiję su prastesniu gebejjimu mentalizuoti, o socialinis nerimas ir su ankstesne traumine patirtimi, ypač smurto patyrimu arba nepriežiūra. Mentalizacija moksliniuose tyrimuose siejama tiek su ịvairiomis ankstyvosiomis traumomis (ypač emociniu apleistumu, seksualine ar fizine prievarta), tiek su vèliau gyvenime atsirandančiomis psichopatologijos formomis. Traumos patyrimas yra sietinas su vèliau besiformuojančiais prastesniais mentalizacijos gebejimais, tad galima hipotezè, kad tokiu atveju prastesnè mentalizacija gali stiprinti socialinio nerimo patyrimą traumą patyrusiujų grupeje.

Aptarti tyrimai iki galo neparodè, kokios sąveikos yra tarp trauminès patirties, socialinio nerimo patyrimo bei gebejjimo mentalizuoti ankstyvojoje paauglysteje.

Tyrimo tikslas - atskleisti trauminès patirties sąsają su socialiniu nerimu bei mentalizacija.

\section{Tyrimo medžiaga ir metodai}

Tyrimo dalyviai. Tyrime dalyvavo $68011-14 \mathrm{~m}$. paauglių $(\mathrm{M}=12,58 ; \mathrm{SD}=0,87), 331$ vaikinas $(\mathrm{M}=12,62$; $\mathrm{SD}$ $=0,87)$ ir 349 merginos $(\mathrm{M}=12,53 ; \mathrm{SD}=0,90)$. Tyrimas vykdytas patogiosios atrankos būdu pasirinktose miestų bei rajonų mokyklose ir vaikų globos namuose.

Tyrimo instrumentai. Tyrimo metu naudotas tyrimo vykdytojų sudarytas klausimynų rinkinys.

Demografinių duomenų anketa sukurta siekiant gauti informaciją apie vaiko gyvenamają vietą, mokyklą, šeimos sudètį, anksčiau išgyventas stresines situacijas.

Reflektyviosios funkcijos klausimynas. Klausimyną sudaro 46 teiginiai skirti ịvertinti paauglių reflektyviają funkciją. Teiginiai vertinami 6 balų skalejje, kur 1 atitinka „,visiškai nesutinku“, o 6 -, ,visiškai sutinku“. Analizuojant šiuo tyrimu surinktus duomenis, gautas Kronbacho (Cronbach) $\alpha$ ịvertis siekia 0,70 , kas nurodo pakankamą skalès patikimumą.

Vaikystės patirčių klausimynas [15]. Klausimynas skirtas įvertinti, su kokiomis traumuojančiomis patirtimis asmuo susidūrè vaikysteje. Klausimai apima emocinị ir fizinị smurtą bei apleistumą. Klausimynas parengtas remiantis Nepalankių vaikystès patirčių klausimynu (angl. Adverse Childhood Experience Questionnaire) [16]. Galutinị klausimyno variantą sudaro 10 klausimų, vertinamų atsakymais „taip“ arba „ne“.

Liebowitz socialinio nerimo skalè vaikams ir paaugliams [17]. Skalę sudaro 24 situacijos, skirtos ịvertinti paauglių 
patiriamam socialinio nerimo lygiui. Tyrimui išverstos lietuviškos instrumento versijos Kronbacho $\alpha$ ịverčiai svyruoja tarp 0,85 ir 0,90 ir nurodo ị pakankamą skalès patikimumą. Vertinant konvergentinį validumą naudota Lietuvoje standartizuota ASEBA grupès skalè paauglių elgesio ir emocijų sunkumams ivvertinti - YSR 11/18. Gautos vidutinio stiprumo koreliacijos $(0,51<\mathrm{r}<0,55)$ su instrumento YSR $11 / 18$ nerimą vertinančiomis subskalèmis nurodo, kad šie konstruktai yra susiję.

Tyrimo eiga. Tyrimas buvo atliekamas nuo $2016 \mathrm{~m}$. vasario iki rugsėjo mėnesio. Tyrime dalyvavo tik tie paaugliai, kurie sutiko bei kurių tėvai pateikè raštišką sutikimą. Tyrimo klausimynų pildymas truko $45 \mathrm{~min}$. - 2 val. Paaugliai pildè sudarytus klausimynų paketus „popieriaus ir pieštuko“ forma.

Duomenų apdorojimas. Tyrimo rezultatai apdoroti naudojantis SPSS Statistics 23.0 programiniu paketu bei A. Hayes sukurtu SPSS Process v.2 (2013) ịskiepiu.

\section{Tyrimo rezultatai}

Pirmiausia pateikiami duomenys apie paauglių subjektyvių smurto patirčių ịvardijimą. Analizuojant subjektyvias smurto patirtis, rezultatai atskleidžia, kad 26,2\% dalyvių ịvardija patyrę bent vienos rūšies smurtą.

1 paveikslèlyje matome, jog dažniausiai fiksuota smurto rūšis yra emocinis apleistumas, antroji pagal dažni - emocinis smurtas.

Toliau pateikiami duomenys analizuojant sąveikas tarp patirto smurto bei kitų konstruktų. Duomenys atskleidžia, kad subjektyviai patyrę visų rūšių smurtą paaugliai pasižymi didesniais socialinio nerimo įverčiais. Tokie pat rezultatai gauti ir analizuojant skirtingas socialinio nerimo subskales (1 lentelè).

Vertinant ryšius tarp tiriamų konstruktų, randamos silpnos, tačiau reikšmingos koreliacijos tarp subjektyvaus smurto patyrimo bei socialinio nerimo, kas nurodo, jog di-

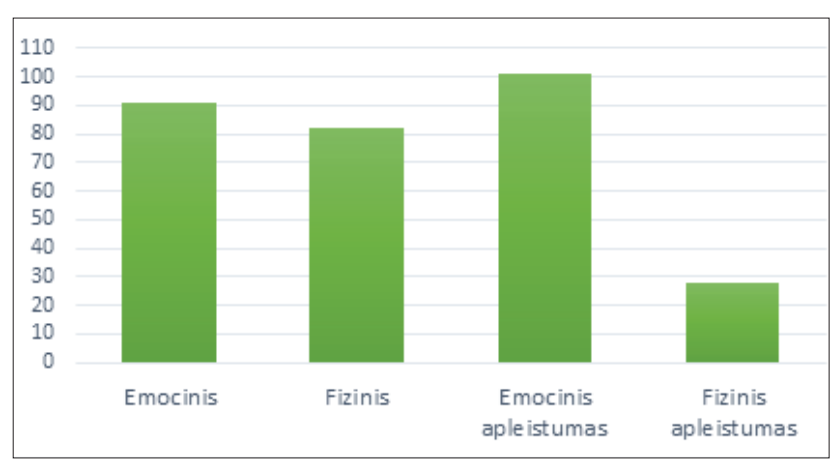

1 pav. Skirtingų smurto rūšių dažniai ankstyvojoje paauglystejeje. Pastaba. X ašyje nurodytos smurto rüšys, o $Y$-skirtingu rüšiu smurto patyrima ivardijusiu paaugliu skaičius. dejjant socialiniam nerimui, didejja ir bendro emocinio $(\mathrm{r}$ $=0,26 ; \mathrm{p}<0,001)$ bei fizinio smurto $(\mathrm{r}=0,11 ; \mathrm{p}<0,001)$ ìvardijimo dažnis. Visa tai nurodo, jog trauminès patirties buvimas yra susijęs su vèliau patiriamu aukštesniu socialinio nerimo lygiu, lyginant su paaugliais, kurie trauminiu patirčių neịvardijo.

Kitas svarbus tyrimo aspektas - trauminès patirties ryšys su mentalizacijos raiška paauglystèje. İtraukus i analizę mentalizacijos konstruktą nustatyta, kad patyrusių smurtą paauglių reflektyvioji funkcija yra prastesnè nei smurto patirčių neịvardijusių (2 lentelè).

Tai reiškia, jog subjektyviai patirtas smurtas, kaip trauminè patirtis, yra reikšmingas kintamasis vertinant reflektyviosios funkcijos skirtumus paauglysteje.

Žvelgiant i duomenis dar giliau, remiantis teorija bei esančiais duomenimis mėginta patikrinti reflektyviosios funkcijos kaip moderatoriaus vaidmenį. Sukurtas modelis yra statistiškai reikšmingas (3 lentelè).

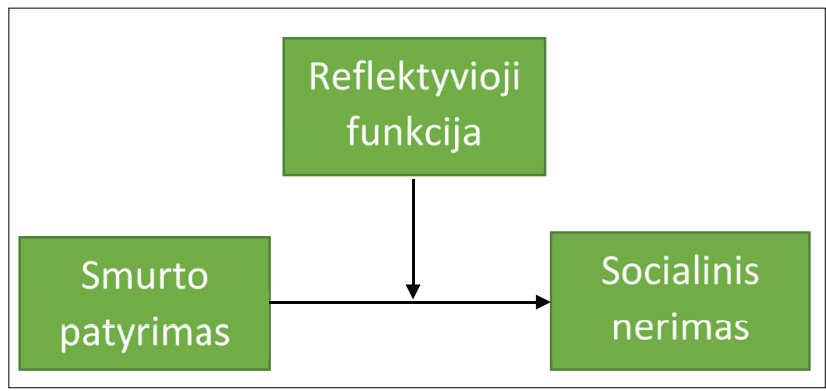

2 pav. Moderacijos modelis prognozuojant socialinio nerimo patyrimą.

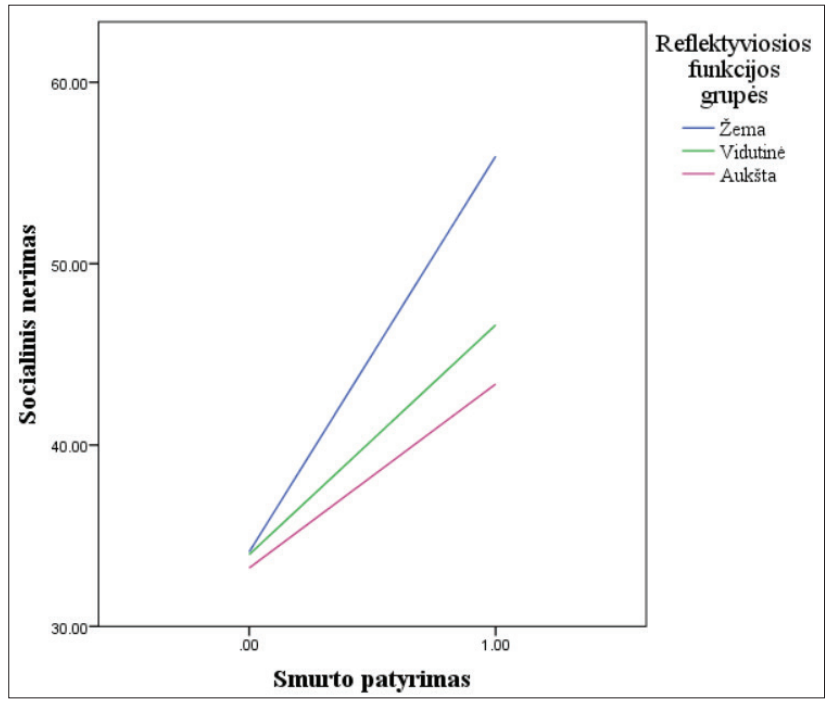

3 pav. Moderacijos efektas atsižvelgiant ị reflektyviosios funkcijos raišką. 
Remiantis gautais duomenimis, sudarytas modelis atitinka tokią schemą ( 2 pav.).

Kuriant modelį buvo išskirtos trys reflektyviosios funkcijos įverčiu grupès, atskiriančios žemą, vidutinị ir aukštą reflektyvios funkcijos lygị turinčius paauglius. Duomenys įrodo, kad sudarytas moderacijos modelis leidžia ịvertinti, kurioje reflektyviosios funkcijos paaugliu grupeje stebimas didžiausias efektas. Siekiant įvertinti ne tik modelio tinkamumą, bet ir efekto dydžius buvo standartizuojami matuojamų kintamųų įverčiai ir pateikiamas efekto ịvertis kiekvienai reflektyviosios funkcijos grupei.Atlikus analizę 4 lentelèje ir 3 paveikslèlyje matome, kad moderacijos efektas mažeja didejjant reflektyviosios funkcijos įverčiams.

Siekiant rezultatus aptarti dar detaliau ir išskirti ribą, kuomet moderacijos efektas išnyksta, taikytas Johnson-Neyman metodas. Reflektyviosios funkcijos kaip moderatoriaus efektas yra, ir tai matome iš to, kad esant žemiausiai bei vidutinei reflektyviajai funkcijai, smurto patyrimo ir socialinio nerimo ryšys yra reikšmingiausias, o moderacijos efektas - didžiausias, tuo tarpu tarp 28,02\% aukščiausius reflektyviosios funkcijos ịverčius surinkusių paauglių moderacijos efektas išnyksta.

Apibendrinant, atlikta statistinè analizè leidžia teigti, kad reflektyvioji funkcija moderuoja sąveiką tarp smurto patyrimo ir socialinio nerimo tokiu būdu, kad esant smurto patirčiai bei mažejjant reflektyviai funkcijai, socialinio nerimo patyrimas didèja.

\section{Rezultatų aptarimas}

Atliktu tyrimu buvo siekiama ịvertinti socialinio nerimo, reflektyviosios funkcijos ir trauminès patirties ypatumus paauglysteje bei atskleisti sąsajas tarp šių konstruktų.

Mokslininkai yra įrodę, jog prastesni mentalizacijos gebẻjimai sietini su socialinių kompetencijų trūkumu, o patiriantys socialinį nerimą asmenys yra linkę kitiems priskirti intensyvesnes emocijas ir suteikti daugiau reikšmés kitų mintims ir jausmams [18]. Taip pat manoma, kad nerimastingi asmenys pasižymi prastesne emocijų reguliacija bei emocijų slopinimu [7]. Vis dèlto ankstesniuose tyrimuose nebuvo analizuotos tiesioginès sąsajos tarp socialinio nerimo ir mentalizacijos. Atlikto tyrimo rezultatai atskleidžia, kad didejant socialinio nerimo patyrimui ịvairiose situacijose mažèja reflektyviosios funkcijos įverčiai. Tad galima kelti
1 lentelè. Socialinio nerimo ịverčiai smurtą patyrusių ir nepatyrusių paauglių grupèse.

Pastaba. $M$ - vidurkis, SD - standartinis nuokrypis. Statistiškai reikšmingi skirtumai pažymèti pajuodintu šriftu.

\begin{tabular}{|l|c|c|c|c|c|}
\hline \multirow{2}{*}{ Smurto rūšis } & Patyrę & Nepatyrę & \multirow{2}{*}{$\mathbf{U}$} & $\mathbf{Z}$ & $\mathbf{p}$ \\
\cline { 2 - 5 } & $\mathbf{M}(\mathbf{S D})$ & $\mathbf{M}(\mathbf{S D})$ & & & \\
\hline Emocinis & $48,38(29,45)$ & $34,23(22,97)$ & 8881,00 & $-3,53$ & $<\mathbf{0 , 0 0 1}$ \\
\hline Fizinis & $46,13(33,35)$ & $34,74(22,65)$ & 8574,00 & $-2,24$ & $\mathbf{0 , 0 2 5}$ \\
\hline $\begin{array}{l}\text { Emocinis apleistu- } \\
\text { mas }\end{array}$ & $53,44(23,35)$ & $33,36(23,44)$ & 6450,50 & $-5,90$ & $<\mathbf{0 , 0 0 1}$ \\
\hline Fizinis apleistumas & $53,72(32,65)$ & $35,44(23,77)$ & 2611,50 & $-2,41$ & $\mathbf{0 , 0 1 6}$ \\
\hline
\end{tabular}

2 lentelè. Patyrusių ir nepatyrusių smurto reflektyviosios funkcijos įverčių palyginimas.

Pastaba. $M$ - vidurkis, SD - standartinis nuokrypis. Statistiškai reikšmingi skirtumai pažymėti pajuodintu šriftu.

\begin{tabular}{|l|c|c|c|c|c|}
\hline \multirow{2}{*}{ Smurto rūšis } & Patyrę & Nepatyrę & \multirow{2}{*}{$\mathbf{U}$} & $\mathbf{Z}$ & $\mathbf{p}$ \\
\cline { 2 - 5 } & $\mathbf{M}(\mathbf{S D})$ & $\mathbf{M}(\mathrm{SD})$ & & & \\
\hline Emocinis & $8,19(0,81)$ & $8,50(0,68)$ & 16061,50 & $-3,20$ & $\mathbf{0 , 0 0 1}$ \\
\hline Fizinis & $8,16(0,81)$ & $8,50(0,68)$ & 13282,00 & $-3,51$ & $\begin{array}{c}< \\
\mathbf{0 , 0 0 1}\end{array}$ \\
\hline Emocinis apleistumas & $8,19(0,83)$ & $8,51(0,67)$ & 17218,00 & $-3,47$ & $\mathbf{0 , 0 0 1}$ \\
\hline Fizinis apleistumas & $8,01(0,85)$ & $8,48(0,69)$ & 4076,50 & $-2,56$ & $\mathbf{0 , 0 1 1}$ \\
\hline
\end{tabular}

3 lentelè. Socialinio nerimo ịverčių prognozė pagal smurto patirtị ir reflektyviają funkciją.

Pastaba. Statistiškai reikšmingi rezultatai pažymèti pajuodintu šriftu.

\begin{tabular}{|c|c|c|c|c|c|}
\hline \multirow[t]{2}{*}{$\begin{array}{l}\text { Nepriklausomi } \\
\text { kintamieji }\end{array}$} & \multicolumn{2}{|c|}{$\begin{array}{c}\text { Priklausomas } \\
\text { kintamasis } \\
\text { Socialinis nerimas }\end{array}$} & \multirow[b]{2}{*}{$\mathbf{F}$} & \multirow[b]{2}{*}{$\mathbf{p}$} & \multirow[b]{2}{*}{$\mathbf{R}^{2}$} \\
\hline & B & $\mathbf{p}$ & & & \\
\hline Smurto patirtis & 14,27 & $<0,001$ & 6,73 & $<0,001$ & 0,08 \\
\hline Reflektyvioji funkcija & $-1,92$ & 0,044 & & & \\
\hline Kintamųų sąveika & $-5,90$ & 0,035 & & & \\
\hline Konstanta & 37,37 & 0,028 & & & \\
\hline
\end{tabular}

4 lentelè. Socialinio nerimo ịverčių prognozè pagal smurto patirtị ir reflektyviają funkciją.

Pastaba. Statistiškai reikšmingi rezultatai pažymèti pajuodintu šriftu.

\begin{tabular}{|l|c|c|c|c|c|}
\hline $\begin{array}{l}\text { Reflektyvioji } \\
\text { funkcija }\end{array}$ & $\begin{array}{c}\text { Moderaci- } \\
\text { jos efektas }\end{array}$ & $\mathbf{t}$ & $\mathbf{p}$ & LLCI & ULCI \\
\hline Žema & 18,54 & 3,84 & $<\mathbf{0 , 0 0 1}$ & 9,0593 & 28,0164 \\
\hline Vidutinė & 14,27 & 4,26 & $<\mathbf{0 , 0 0 1}$ & 7,6805 & 20,8651 \\
\hline Aukšta & 10,01 & 2,10 & $\mathbf{0 , 0 3 7}$ & 0,6170 & 19,3985 \\
\hline
\end{tabular}




\section{4}

hipotezę, kad kuo žemesnès yra mentalizacijos galimybės, tuo daugiau patiriama socialinio nerimo.

Analizuojant nepalankias vaikystės patirtis, nustatyta, kad bendroje imtyje $26,2 \%$ paauglių yra patyrę bent vienos rūšies smurtą, o dažniausiai ịvardytas emocinio smurto patyrimas. Matome, kad beveik trečdalis apklaustų paauglių subjektyviu jų teigimu kažkuriuo gyvenimo laikotarpiu patyrè smurtą. Paaugliai, patyrę bet kokios rūšies smurtą, pasižymi prastesniais reflektyviosios funkcijos gebejjimais. Tai sutampa su tyrimų duomenimis apie trauminių patirčių neigiamą įtaką bendrai mentalizacijos bei emocijų atpažinimo gebejjimo raidai [13]. Trauminès patirtys šiuo atveju sutrikdo tolimesnę vaiko raidą, o paauglystejje jau stebimi mentalizacijos gebejjimų skirtumai.

Vertinant socialinio nerimo ryši su nepalankiomis vaikystès patirtimis, nustatyta, kad patyrę bet kokios rūšies smurtą paaugliai patiria statistiškai reikšmingai daugiau socialinio nerimo nei nepatyrę, kas sutampa su duomenimis apie nepalankių vaikystès ịvykių ryšị su didesniu nerimastingumu [12]. Analizuojant sąsajas tarp šių procesų atskleista, kad didejant socialinio nerimo patyrimui, didejja ir emocinio bei fizinio smurto ịverčiai. Tai parodo, kad ankstyva trauminè smurto patirtis yra susijusi su didesniu nerimastingumu vèlesniame amžiuje.

Šiuo tyrimu taip pat buvo siekta atskleisti aptariamu veiksnių sąveiką. Sudarytas moderacijos modelis leidžia diferencijuoti žema, vidutine ir aukšta reflektyviaja funkcija pasižyminčius paauglius, vertinant, kaip tai yra susiję su smurto patirtimi bei socialiniu nerimu. Remiantis šiuo modeliu, galima teigti, kad tarp žemus ir vidutinius reflektyviosios funkcijos gebejjimus turinčių paauglių yra reikšmingiausia ir stipriausia sąveika tarp smurto ir socialinio nerimo patyrimo, tuo tarpu tarp 28,02\% aukščiausius ịverčius surinkusiųjų moderacijos efektas išnyksta. Tai dera su ịprastai literatūroje pateikiama idejja, kad žema reflektyvioji funkcija yra susieta su prastesniu funkcionavimu [10], kas šiuo atveju būtų socialinio nerimo patyrimas. Taip pat vertinant kitą kraštutinumą - aukštą reflektyviają funkciją - pagrindimą galima rasti psichikos teorijos tyrimuose, kuriais įrodyta, kad geresnę reflektyviają funkciją turinčiujjų grupejje stebima mažiau psichikos sveikatos problemų [19]. Taigi, galima teigti, kad esant geresnei mentalizacijai, smurto patyrimo ir socialinio nerimo sąveika yra silpnesne, o šis ryšys visai išnyksta aukščiausius mentalizacijos gebejjimus turinčiuju grupèje. Visa tai įrodo žemos ir vidutinès reflektyviosios funkcijos svarbą smurto patirties ir socialinio nerimo sąveikoje ir išryškina geros mentalizacijos kaip apsaugančio veiksnio funkciją.

Apibendrinant, tyrime dalyvavo didelis kiekis paaugliu iš skirtingų miestų ir kaimų mokyklų bei globos namų. Nors tirtos imties negalime laikyti reprezentatyvia, tyrimo rezulta- tai rodo svarbius bendrus jaunesniujų paauglių trauminès patirties, mentalizacijos ir socialinio nerimo sąveikų aspektus. Gauti rezultatai atskleidžia trauminès patirties (šiuo atveju - smurto patyrimo) svarbą vaiko raidoje. Patirtas smurtas tirtoje imtyje sietinas tiek su didesniu socialinio nerimo lygiu, tiek su prastesne reflektyviaja funkcija. Galiausiai, rezultatai rodo, jog prastesnè reflektyvioji funkcija yra sietina su stipresniu socialiniu nerimu subjektyviai smurtą patyrusiujų paaugliu grupejje. Taigi, mentalizacija šiame tyrime atsiskleide kaip svarbus veiksnys, galintis atlikti netgi apsauginę funkciją kalbant apie vèlesnị paauglio psichosocialinį sutrikdymą. Atsižvelgiant ị tai, galima manyti, jog mentalizacijos gebėjimo ugdymas bet kuriame raidos periode gali padèti paaugliui adaptyviai susidoroti tiek su vaikysteje patirtais sunkumais, tiek su paauglystėje kylančiais iššūkiais.

\section{Išvados}

1. Prastejjant reflektyviajai funkcijai, didejja paauglių socialinio nerimo ịverčiai.

2. Smurto patirtis įvardiję paaugliai patiria daugiau socialinio nerimo nei jų nepatyrę, o jų reflektyvioji funkcija yra žemesnè.

3. Esant žemai ir vidutinei reflektyviajai funkcijai nustatyta stipriausia sąveika tarp subjektyvios smurto patirties ir socialinio nerimo.

4. Aukšta reflektyvioji funkcija šio tyrimo ribose atlieka apsauginio veiksnio funkciją.

\section{Literatūra}

1. Wenar C, Kerig P. Middle chilhood: the anxiety disorders. In: Developmental Psychopathology. 5th ed. New York: McGrawHill Companies; 2005:215-246.

2. Žukauskienè R. Paauglystė. In: Raidos psichologija. Vilnius. Margi raštai, 2002; 295-332.

3. American Psychiatric Association. DSM-5 Diagnostic and Statistical Manual of Mental Disorders. 5th ed. London. American Psyciatric Publishing, 2013.

4. Soohinda G, Sampath H. Social phobia among school students - prevalence, demographic correlates and socio-academic impairment. J Indian Assoc Child Adolesc Ment Heal 2016;12(13):211-229.

5. Ranta K, Kaltiala-Heino R, Rantanen P, Marttunen M. Social phobia in Finnish general adolescent population: prevalence, comorbidity, individual and family correlates, and service use. Depress Anxiety 2009; 26(6):528-536. doi:10.1002/da.20422 https://doi.org/10.1002/da.20422

6. Burklund LJ, Craske MG, Taylor SE, Lieberman MD. Altered emotion regulation capacity in social phobia as a function of comorbidity. Soc Cogn Affect Neurosci 2015;10(2):199-208. doi:10.1093/scan/nsu058

https://doi.org/10.1093/scan/nsu058 
7. Calvete E, Riskind JH, Orue I, Gonzalez-Diez Z. Recursive associations among maladaptive cognitions and symptoms of social anxiety and depression: implications for sex differences. J Soc Clin Psychol 2016; 35(10):807-821.

https://doi.org/10.1521/jscp.2016.35.10.807

8. Ha C, Sharp C, Ensink K, Fonagy P, Cirino P. The measurement of reflective function in adolescents withand without borderline traits. J Adolesc 2013; 36(6):1215-1223.

https://doi.org/10.1016/j.adolescence.2013.09.008

9. Fonagy P, Gergely G, Jurist EL, Target M. Affect regulation, mentalization and the development of the self. Vol 0. New York. Other Press, 2002.

10. Ostler T, Bahar OS, Jessee A. Mentalization in children exposed to parental methamphetamine abuse: relations to children's mental health and behavioral outcomes. Attach Hum Dev 2010; 12(3):193-207.

https://doi.org/10.1080/14616731003759666

11. Smith JD. Focusing on reflections: mentalization and mirroring in brief dynamic therapy. Br J Psychother 2014; 30(2):212-228. https://doi.org/10.1111/bjp.12078

12. Simon NM, Sc M, Herlands NN. et al. Childhood maltreatment linked to greater symptom severity and poorer quality of life and function in social anxiety disorder. NIH Public Access 2010; 26(11):1027-1032.

13. Dimitrijevic A. Trauma as a neglected etiological factor of mental disorders. Sociologija 2015; 57(2):286-299.

https://doi.org/10.2298/SOC1502286D

14. Ensink K, Normandin L, Target M, Fonagy P, Sabourin S, Berthelot N. Mentalization in children and mothers in the context of trauma: an initial study of the validity of the Child Reflective Functioning Scale. Br J Dev Psychol 2015; 33(2):203-217. https://doi.org/10.1111/bjdp.12074

15. Gervinskaitė-Paulaitienė L., BaškytėAM., Čènaitė N., Matutytė L., Šiaučiūnaitè M., Barkauskienė R. Suvoktas smurto patyrimas, emocijų reguliacija ir somatiniai sunkumai ankstyvojoje paauglysteje. Sveikatos mokslai, 2017; 27(3):11-17. https://doi.org/10.5200/sm-hs.2017.032

16. Felitti VJ, Anda RF, Nordenberg D. et al. Relationship of childhood abuse and household dysfunction to many of the leading causes of death in adults. Am J Prev Med 1992; 14(4):245-258. https://doi.org/10.1016/S0749-3797(98)00017-8

17. Masia-Warner C, Storch EA, Pincus DB, Klein RG, Heimberg RG, Liebowitz MR. The Liebowitz social anxiety scale for children and adolescents: an initial psychometric investigation.
J Am Acad Child Adolesc Psychiatry 2003; 42(9):1076-1084. https://doi.org/10.1097/01.CHI.0000070249.24125.89

18. Hezel DM, McNally RJ. Theory of mind impairments in social anxiety disorder. Behav Ther 2014; 45(4):530-540.

https://doi.org/10.1016/j.beth.2014.02.010

19. Tomlinson E, Onwumere J, Kuipers E. Distress and negative experiences of the caregiving relationship in early psychosis: does social cognition play a role? Early Interv Psychiatry 2014; 8(3):253-260.

https://doi.org/10.1111/eip.12040

\section{ADOLESCENTS' SOCIAL ANXIETY,} MENTALIZATION AND TRAUMATIC EXPERIENCE G.Skabeikytė, R.Barkauskienė, L.Gervinskaitė-Paulaitienė

Key words: social anxiety, mentalization, traumatic experience, adolescence.

Summary

The aim of this study was to analyse the relationship between adolescents' social anxiety, mentalization and trauma. Social anxiety is a relevant problem in adolescence that causes impairments in psychosocial functioning. Research reveal that childhood traumatic experiences are associated with higher anxiety levels in later years. Also, social anxiety is defined through inaccurate interpretations of others behavior and in that way it may be linked to mentalization impairments. However, there is no empirical evidence about social anxiety relations to mentalization and it is unknown what part does the trauma account for in this relationship. This topic in Lithuania is quite new and there is a need for valid instrument assesing adolescents' social anxiety. Participants were $68011-14$ year olds (331 boys and 349 girls) from different schools and orphanages in Lithuania. Instruments. Liebowitz social anxiety scale for children and adolescents (LSAS-CA), Reflective function questionnaire for youth (RFQY) and Adverse childhood experiences questionnaire (ACE). Results. Traumatic experience is associated with poorer reflective function and higher social anxiety levels. Higher social anxiety levels are associated with poorer reflective function. The relationship between social anxiety and trauma is moderated by levels of reflective function: the strongest relationship is in low and moderate reflective function groups. The highest reflective function acts as a protective factor.

Correspondence to: gabriele.skabeikyte@fsf.vu.lt

Gauta 2019-02-20 